\title{
Development, validation and application of a Brazilian knowledge scale about sports doping in dentistry
}

\author{
Lucas Alves JURAL (a) \\ Thais Rodrigues Campos SOARES(a) \\ Raildo da Silva COQUEIRO(b) \\ Tiago Braga RABELLO(c) \\ Matheus Melo PITHON(a) \\ Lucianne Cople MAIA(a) \\ (a) Universidade Federal do Rio de Janeiro - \\ UFRJ, School of Dentistry, Department of \\ Pediatric Dentistry and Orthodontics, Rio de \\ Janeiro, RJ, Brazil. \\ (b) Universidade Estadual do Sudoeste da \\ Bahia - UESB, Center for Studies in Aging, \\ Jequié, BA, Brazil. \\ (c) Universidade Federal do Rio de Janeiro - \\ UFRJ, School of Dentistry, Department of \\ Dental Clinic, Rio de Janeiro, RJ, Brazil.
}

Declaration of Interests: The authors certify that they have no commercial or associative interest that represents a conflict of interest in connection with the manuscript.

Corresponding Author:

Lucianne Cople Maia

E-mail: rorefa@terra.com.br

https://doi.org/10.1590/1807-3107bor-2021.vol35.0110

Submitted: October 29, 2020

Accepted for publication: March 29, 2021

Last revision: April 27, 2021
Abstract: To evaluate the knowledge of Brazilian dentists of sports doping through the development, validation and application of the Brazilian Knowledge Scale about Sports Doping in Dentistry (B-KSSDD). A scale with 12 items was developed to assess a dentist's ability to determine whether the use of a medication characterised sports doping according to the World Anti-Doping Agency. A preliminary study to validate the B-KSSDD was carried out with 135 dentists, allowing the evaluation of ceiling and floor effects, convergent and discriminant validity, test-retest reliability and internal consistency of the instrument. A sample size calculation using the results of the preliminary study and the B-KSSDD was completed online using SurveyMonkey ${ }^{\circledR}$ by 270 participants from all regions of the country. The B-KSSDD showed evidence of convergent and discriminant validity, good temporal stability $(\mathrm{ICC}=0.75)$ and internal consistency (alpha $=0.89$ ). In the main study, the participants obtained an average score of 4.19/12 points on the B-KSSDD, suggesting that these professionals have insufficient knowledge about sports doping. The age of participants showed a negative association with knowledge about doping, while frequency of treating athletes and frequency of performing surgeries showed positive associations with knowledge about doping. The dentists had insufficient knowledge of the subject. Age of participants and frequency with which they attend to athletes are associated with knowledge about sports doping. Professional updating and education policies on doping are necessary for dentists, as athlete patients are at risk for severe sporting and financial penalties.

Keywords: Pharmaceutical Preparations; Dentists; Educational Measurement; Sports Medicine; Doping in Sports.

\section{Introduction}

The term doping was formally defined in 1889, when an English dictionary described it as a mixture of opium and narcotics in horses. ${ }^{1}$ However, the use of doping substances in horses and athletes arose in the Roman period, when they were used to increase the capacity and strength of these animals and gladiator athletes as the prestige of sports grew. ${ }^{2}$ With the evolution of sports and the advent of sports medicine, 
the International Federation of Sports Medicine defined sports doping as the act of an athlete intentionally or unintentionally using substances or methods prohibited by the International Olympic Committee (IOC). ${ }^{3}$ In 2002, the World Anti-Doping Agency (WADA) published the World Anti-Doping Code (Code) ${ }^{4}$, which determined doping control guidelines and was adopted by more than 660 sports entities, including the IOC, the International Paralympic Committee, international federations and national anti-doping organisations.

In addition to the Code, which was last published in 2015, the WADA annually publishes an updated list of prohibited substances that can potentially be used for doping in athletes, since they can induce an artificial increase in athletes' sports performance. The Code also addresses the sanctions applicable to athletes, teams or even sports entities, ranging from the loss of medals, points and prizes to financial consequences. ${ }^{4,5}$

The document updated annually by the WADA includes substances belonging to different therapeutic classes, such as anabolic agents, hormones and metabolic modulators, stimulants and glucocorticoids, that can be banned both during and outside the competition period. ${ }^{5}$ Many of the drugs included in this list can be purchased in pharmacies over the counter or by prescription from health professionals such as doctors and dentists, who may inadvertently prescribe their use. Sometimes dental care may require the dentist to prescribe medications such as glucocorticoids and stimulants that, when used by athletes, can be characterised as sports doping, making the athlete susceptible to serious penalties., ${ }^{4,6,7}$ For this reason, it is essential that dentists are knowledgeable about sports doping and are prepared to assist athletes without putting them at risk of positive results in doping tests.

In view of the lack of studies assessing the knowledge of dentists about sports doping and substances forbidden for athletes, the objective of this study was to report the development, validation and application of the Brazilian Knowledge Scale about Sports Doping in Dentistry (B-KSSDD).

\section{Methodology}

The study was conducted in accordance with the 1964 Helsinki Declaration and approved by the Research Ethics Committee of Clementino Fraga Filho University Hospital, at Federal University of Rio de Janeiro (protocol no. 3.940.568). All participants signed informed consent forms in order to take part in the study.

\section{Study design and participants}

This cross-sectional study included Brazilian dentists of both genders from all regions of the country, including dentists with professional registration at their respective regional dentistry councils. Participants in the preliminary and main studies answered an electronic questionnaire, hosted by SurveyMonkey Inc. (San Mateo, USA), that tested the professionals' knowledge about medicines that, when used by athletes, do or do not characterise sports doping.

The questionnaire consisted of questions on the participants' sociodemographic and professional information; a question on self-assessment of their knowledge about sports doping, ranging from 1 (none) to 5 (excellent); and the B-KSSDD in Brazilian Portuguese.

\section{Preliminary study: development and validation of the B-KSSDD}

Before beginning the main study, the questionnaire was developed and validated in six steps: a) elaboration of the questions; b) specialised technical evaluation; c) general evaluation by dentists; d) evaluation of linguistics and comprehensibility; e) finalisation of the B-KSSDD; and f) assessment of the validity and reliability of the B-KSSDD (test-retest).

\section{Elaboration of the questions}

One graduate student in dentistry, one endodontist, one paediatric dentist and one orthodontist consulted the Code and Prohibited List ${ }^{4,5}$ and investigated the absence or presence of drugs with potential use in dental practice (such as non-steroidal antiinflammatory, glucocorticoids and analgesics). The scale's questions were closed and contained 
medications with potential or not to cause doping according to WADA documents ${ }^{4,5}$ and adopted the following model:

The use of [DRUG AND ADMINISTRATION] (for example, [COMMERCIAL NAME]), prescribed by a dental surgeon to an athlete who is in competition, characterises sports doping.

Answer: Agree / Disagree / Don't know

\section{Specialised technical evaluation}

The questions were submitted to a dentist specialised in Sports Dentistry. This professional was asked whether the scale effectively assessed the dentist's knowledge about sports doping. After the professional's evaluation, his suggestions were incorporated or modified in the instrument.

\section{General evaluation by dentists}

Ten dentists (three oral and maxillofacial surgeons, one stomatologist, one periodontist, one orthodontist, one restorative dentist, two paediatric dentists and one general dentist) evaluated the clarity and comprehensibility of the B-KSSDD.

\section{Linguistic and comprehensibility evaluation}

The questions were submitted to a journalist and an educator, who evaluated the linguistic and grammatical aspects of the B-KSSDD.

\section{Finalisation of the Brazilian Knowledge Scale about Sports Doping in Dentistry (B-KSSDD)}

The considerations and suggestions made by the evaluators were analysed and incorporated into the scale. The final version of the scale has 12 objective questions that evaluate the dentists' knowledge about the substances forbidden for use by athletes subject to doping control, as determined by the WADA. Each question offers three answer options: 'agree', 'disagree' or 'don't know'. For each correct answer, 1 point was added to the participant's final score, while for each incorrect answer or 'don't know', 0 points were added to the score. The final score of each participant could range from 0 (no correct answers/complete lack of knowledge) to 12 points (complete knowledge). As the professionals were Brazilian, the questions were provided in Portuguese (Table 1).

\section{Validity and reliability of the questionnaire}

The questionnaire test was given to 135 general dentists or specialists (from 16 different specialties), and 15 days later, 50 of these professionals were randomised using BioEstat 5.3 (Instituto Mamirauá, Belém, Brazil) to complete a retest of the questionnaire. These professionals were not included in the main study.

The validation analysis assessed the following data: floor and ceiling effects, by analysing the frequency of responses for each total score of the scale; ${ }^{8}$ convergent construct validity, by assessing the correlation between the B-KSSDD score and the selfreported knowledge score on sports doping using Spearman's correlation (correlation coefficients < $0.4=$ weak magnitude correlation, $\geq 0.4$ to $<0.5=$ moderate magnitude and $\geq 0.5=$ strong magnitude) ${ }^{9}$ discriminant construct validity, by comparing the B-KSSDD score between groups of dentists who perform surgeries with lesser or greater frequency using the Mann-Whitney test; reliability, evaluated according to the criteria of temporal stability (agreement between repeated test-retest measures); and internal consistency. The intraclass correlation coefficient (ICC) was calculated for the total score and Cronbach's alpha was calculated for the total scale and for the scale with items deleted, together with the item-total correlation coefficients. An ICC $\geq 0.70$ and a Cronbach's alpha between 0.70 and 0.95 were considered evidence of reliability. ${ }^{8}$

The level of significance adopted in all analyses was $5 \%(\alpha=0.05)$. Data were tabulated and analysed using IBM SPSS Statistics for Windows (IBM SPSS 21.0, 2012, IBM Corp., Armonk, USA).

\section{Main study}

\section{Sample size calculation and application}

Sample size calculation considered the following parameters: effect size $=0.10, a=0.05$, power $=0.95$ and number of predictors $=9$. The effect size was 
Table 1. Original and validated final version of the Brazilian Knowledge Scale about Sports Doping in Dentistry (B-KSSDD) and scores added to the total score according to the participants' responses.

\begin{tabular}{|c|c|c|c|}
\hline $\begin{array}{l}\text { Leia as sentenças a seguir e informe sua concordância, discordância ou ausência de } \\
\text { conhecimento sobre a afirmação apresentada: }\end{array}$ & Concordo & Discordo & Não sei \\
\hline $\begin{array}{l}\text { 1. A utilização de nimesulida via oral (por exemplo, Nisulid }{ }^{\circledR}, \text { Arflex }{ }^{\circledR} \text { ), prescrita por } \\
\text { um cirurgião-dentista a um atleta que está em período de competição, caracteriza } \\
\text { doping esportivo. }\end{array}$ & 0 & 1 & 0 \\
\hline $\begin{array}{l}\text { 2. A utilização de dexametasona via oral (por exemplo, Decadron), prescrita por } \\
\text { um cirurgião-dentista a um atleta que está em período de competição, caracteriza } \\
\text { doping esportivo. }\end{array}$ & 1 & 0 & 0 \\
\hline $\begin{array}{l}\text { 3. A utilização de dipirona via oral (por exemplo, Novalgina }{ }^{\circledR} \text {, Dorflex }{ }^{\circledR} \text {, } \\
\text { Magnopirol }(\text { ), prescrita por um cirurgião-dentista a um atleta que está em período } \\
\text { de competição, caracteriza doping esportivo. }\end{array}$ & 0 & 1 & 0 \\
\hline $\begin{array}{l}\left.\text { 4. A utilização de triancinolona por via tópica (por exemplo, Omcilon }{ }^{\circledR}\right) \text {, prescrita } \\
\text { por um cirurgião-dentista a um atleta que está em período de competição, } \\
\text { caracteriza doping esportivo. }\end{array}$ & 0 & 1 & 0 \\
\hline $\begin{array}{l}\text { 5. A utilização de anestésico local com adrenalina ou epinefrina (por exemplo, } \\
\text { Aplhacaine) administrado por um cirurgião-dentista em um atleta que está em } \\
\text { período de competição caracteriza doping esportivo. }\end{array}$ & 0 & 1 & 0 \\
\hline $\begin{array}{l}\text { 6. A utilização de associação de dipirona com mucato de isometepteno via oral (por } \\
\left.\text { exemplo, na Neosaldina }{ }^{\circledR}\right) \text {, prescrita por um cirurgião-dentista a um atleta que está } \\
\text { em período de competição, caracteriza doping esportivo. }\end{array}$ & 1 & 0 & 0 \\
\hline $\begin{array}{l}\text { 7. A utilização de prednisolona via oral (por exemplo, Predsim }{ }^{\circledR} \text { ), prescrita por } \\
\text { um cirurgião-dentista a um atleta que está em período de competição, caracteriza } \\
\text { doping esportivo. }\end{array}$ & 1 & 0 & 0 \\
\hline $\begin{array}{l}\text { 8. A utilização de amoxicilina via oral (por exemplo, no Amoxil }(\circledR) \text {, prescrita por } \\
\text { um cirurgião-dentista a um atleta que está em período de competição, caracteriza } \\
\text { doping esportivo. }\end{array}$ & 0 & 1 & 0 \\
\hline $\begin{array}{l}\text { 9. A utilização de paracetamol via oral (por exemplo, Tylenol®), prescrita por um } \\
\text { cirurgião-dentista a um atleta que está em período de competição, caracteriza } \\
\text { doping esportivo. }\end{array}$ & 0 & 1 & 0 \\
\hline $\begin{array}{l}\text { 10. A utilização de associação de codeína com paracetamol via oral (por exemplo, } \\
\text { Tylex®), prescrita por um cirurgião-dentista a um atleta que está em período de } \\
\text { competição, caracteriza doping esportivo. }\end{array}$ & 0 & 1 & 0 \\
\hline $\begin{array}{l}\text { 11. A utilização de ibuprofeno via oral (por exemplo, Alivium } ® \text { ), prescrita por um } \\
\text { cirurgião-dentista a um atleta que está em período de competição, caracteriza } \\
\text { doping esportivo. }\end{array}$ & 0 & 1 & 0 \\
\hline $\begin{array}{l}\left.\text { 12. A utilização de betametasona via oral (por exemplo, Celestone }{ }^{\circledR}\right) \text {, prescrita por } \\
\text { um cirurgião-dentista a um atleta que está em período de competição, caracteriza } \\
\text { doping esportivo. }\end{array}$ & 1 & 0 & 0 \\
\hline Escore total da B-KSSDD: & & (0 a 12 pontos) & \\
\hline
\end{tabular}

Respostas corretas são representadas por 1, enquanto as incorretas ou "não sei" são representadas por 0 pontos no escore final da B-KSSDD.

defined through preliminary analysis using data from the 135 individuals who participated in the test phase of the scale. A minimum sample size of 245 individuals was estimated, and with $10 \%$ added to compensate for possible losses, the total number of participants was 270 dentists. The sample size was calculated using G* Power (Version 3.1.9.2, Germany).

Respecting proportionality to the percentage of dentists distributed in each region of the country ${ }^{10}$ (Table 2), general dentists or specialists were asked to answer the validated scale. The professionals
Table 2. Distribution of dentists in each region of the country (Federal Council of Dentistry, 2020)..$^{10}$

\begin{tabular}{lcc}
\hline Country region & $\mathrm{n}$ & $\%$ \\
\hline North & 19,091 & 6 \\
Northeast & 56,112 & 17 \\
Midwest & 29,792 & 9 \\
South & 54,538 & 16 \\
Southeast & 173,63 & 52 \\
Total & 333,163 & 100 \\
\hline
\end{tabular}

The regions of the participants included in the study sample were stratified based on the percentage of dentists registered with the Federal Dentistry Councils of these regions. 
were approached by personal contacts (co-workers, WhatsApp groups, Facebook or e-mail). ${ }^{11}$

\section{Statistical analysis}

Descriptive statistics were used to express the results as relative and absolute frequencies, means, standard deviations (SD), minimum and maximum values and 95\% confidence intervals $(95 \% \mathrm{CI})$. Simple and multiple linear regression analyses were conducted to assess the relationship between sociodemographic and professional characteristics and knowledge about sports doping. The multiple model was built using the backward method, in which all independent variables were initially incorporated into the model and the variables with the highest values of alpha (a) were subsequently removed one by one until the minimum value of 0.20 was reached. Thus, all independent variables that reached $\alpha \leq 0.20$ were maintained in the final model for purposes of adjustment. The level of significance adopted in all analyses was 5\% $(\alpha=0.05)$. Data were tabulated and analysed using IBM SPSS Statistics for Windows (IBM SPSS 21.0, 2012, IBM Corp., Armonk, USA).

\section{Results}

\section{B-KSSDD validation in preliminary study}

On a scale ranging from 1 (none) to 5 (excellent), dentists' self-reported knowledge about sports doping obtained a mean score of $1.88(\mathrm{SD}=0.77)$.

A floor effect was observed, with a response frequency of $23.7 \%$ for the minimum score; in contrast, no ceiling effect was observed, as the response frequency for the maximum score was only $1.5 \%$.

The convergent validity analysis showed a positive and strong correlation $\left(\mathrm{R}_{\text {spearman }}=0.57 ; \mathrm{p}<0.001\right)$ between the B-KSSDD score and the self-reported knowledge score on sports doping. The discriminant validity showed a significant difference in the B-KSSDD score between the groups of dentists who perform surgeries with lower or higher frequency (Figure 1).

Data obtained from the 135 scales completed by dentists were analysed for internal consistency. Cronbach's alpha for the total scale was 0.89 . The item-total correlation coefficients ranged from 0.47 to 0.72 . The alpha values of deleted items ranged from
0.87 to 0.89 . The B-KSSDD scores for the test-retest were $4.30(\mathrm{SD}=3.08)$ and $4.80(\mathrm{SD}=2.84)$, respectively, and the ICC was 0.75 ( $p<0.001 ; 95 \% C I$ : $0.56-0.86$ ).

\section{Application of B-KSSDD in the main study}

The age of the 270 dentists participating in the study ranged from 22 to 86 years (mean $=40.80$; $\mathrm{SD}=12.88)$ and the stratification of dentists by regions of the country was maintained in our sample (Figure 2). Table 3 shows the sociodemographic and professional characteristics. Most of the sample was female, had more than 15 years of training, had graduated from public institutions and had a specialisation. In total, 22 specialties were reported by the participants, including Sports Dentistry $(\mathrm{n}=4 ; 1.5 \%$ ). The four most common specialties were Orthodontics ( $\mathrm{n}=103 ; 38.1 \%)$, Paediatric Dentistry ( $\mathrm{n}=36 ; 13.3 \%$ ), Periodontics and Implantology (both with $\mathrm{n}=21 ; 7.8 \%)$. Among the participants, $70 \%$ and $94.1 \%$ of professionals indicated a low frequency (never, rarely or sometimes) of performing surgeries and treating athletes, respectively.

The average B-KSSDD score obtained by dentists was 4.19 ( $\mathrm{SD}=3.19$; 95\%CI: 3.81-4.57), with $23 \%$ scoring the minimum score (0), $74.4 \%$ scoring below 7 and only $0.4 \%$ reaching the maximum score (12). In addition, we found that, only among specialists in Sports Dentistry, the average score presented was 9.25 (SD = 2.22; 95\% CI: 5.72-12.0).

$$
{ }^{*} \text { p-value }=0.018
$$

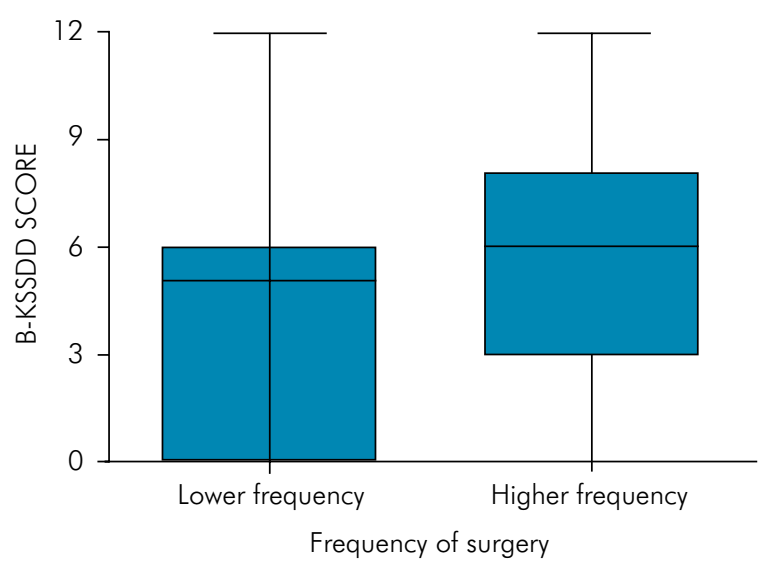

Figure 1. Analysis of the discriminant validity of the Brazilian Knowledge Scale about Sports Doping in Dentistry (B-KSSDD). 


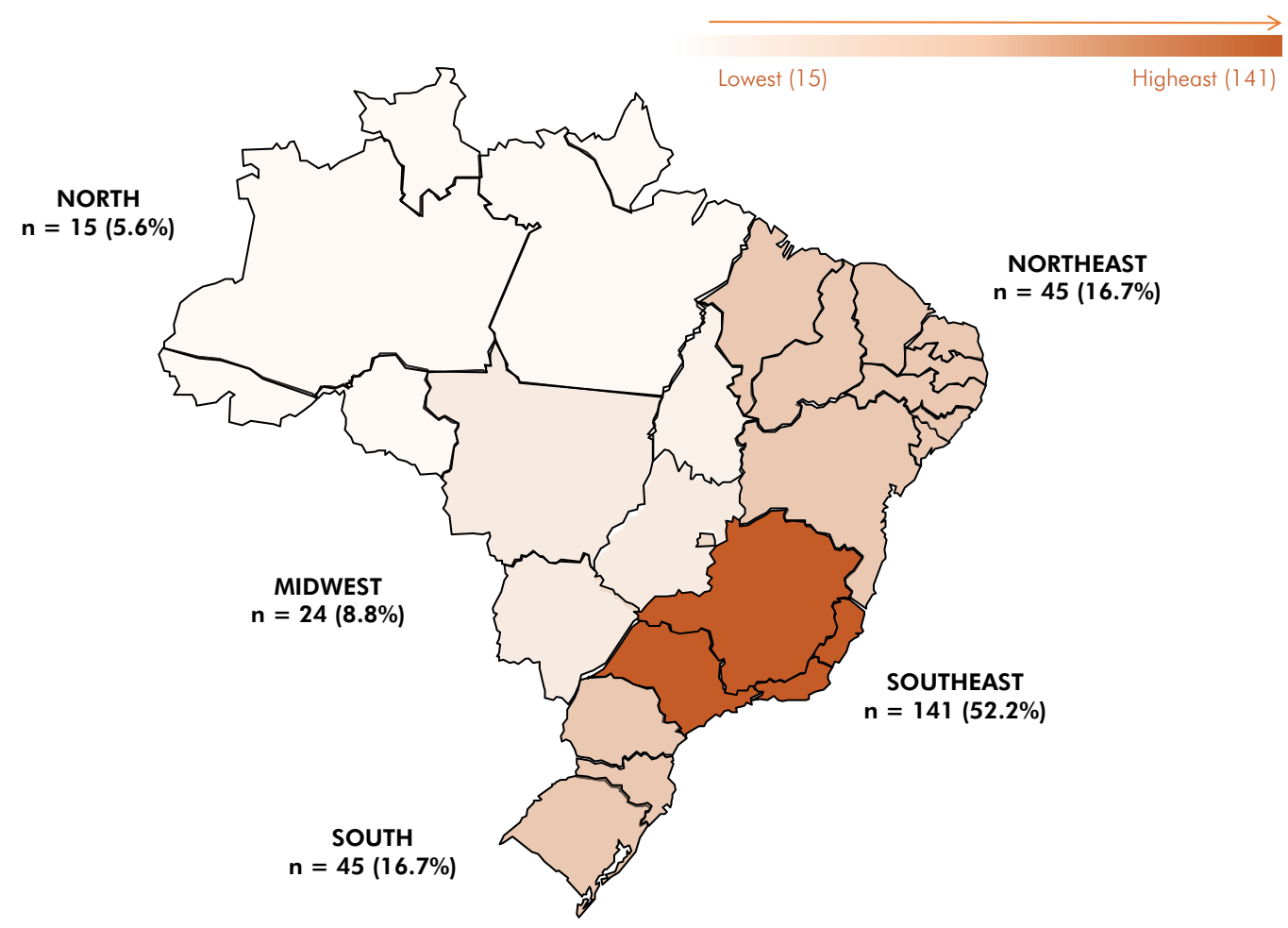

* Mann-Whitney test.

Figure 2. Distribution of sample's dentists in each region of the country.

After applying the multiple linear regression backward method, only three variables (age, frequency of surgery and frequency of treating athletes) remained in the model for predicting knowledge about sports doping, with the other variables (gender, service region, geographic region within the State, time since graduation, institution of graduation and specialisation) were excluded because they did not reach the statistical criterion of permanence in the model $(p \leq 0.20)$. Table 4 shows the results of simple and multiple linear regressions for predicting knowledge about sports doping in the study participants. The univariate model showed that age was negatively associated with B-KSSDD score. In contrast, frequency of performing surgeries and frequency of treating athletes were positively associated with B-KSSDD score. All these associations were maintained in the multiple regression model; therefore, the adjusted analysis indicated that age (negative association) and frequency of performing surgeries and frequency of treating athletes (positive associations) were independent predictors of knowledge about sports doping.

\section{Discussion}

\section{Validity and reliability of B-KSSDD - preliminary study}

The validation of an instrument is a fundamental step to ensure its accuracy in assessing the objectives for which it is proposed to evaluate, and B-KSSDD showed good reliability, as assessed using the criteria of internal consistency and temporal stability (agreement between test-retest). The fact that B-KSSDD has a floor effect but does not have a ceiling effect suggests that dentists have insufficient knowledge about sports doping and the substances that characterise it, in line with the low average score obtained for the question that assessed the professionals' self-reported knowledge about sports doping. The B-KSSDD demonstrated convergent validity, as a positive and strong correlation was observed between the score obtained in the B-KSSDD and the self-reported knowledge score on sports doping, showing that the scale is effective ${ }^{8}$ in assessing the knowledge of dentists about the subject. In addition, the scale 
Table 3. Sociodemographic characteristics of the dentists participating in the study.

\begin{tabular}{|c|c|c|}
\hline Variable & $\mathrm{n}$ & $\%$ \\
\hline \multicolumn{3}{|l|}{ Gender } \\
\hline Female & 166 & 61.5 \\
\hline Male & 104 & 38.5 \\
\hline \multicolumn{3}{|l|}{ Service region } \\
\hline North/Northeast/Midwest & 84 & 31.1 \\
\hline South/Southeast & 186 & 68.9 \\
\hline \multicolumn{3}{|c|}{ Geographic region within the State } \\
\hline Capital & 124 & 46.0 \\
\hline Inland & 146 & 54.0 \\
\hline \multicolumn{3}{|l|}{ Time since graduation (years) } \\
\hline$<1$ & 8 & 2.2 \\
\hline $1-5$ & 63 & 23.3 \\
\hline $6-10$ & 39 & 14.4 \\
\hline $11-15$ & 26 & 9.6 \\
\hline $16-25$ & 57 & 21.1 \\
\hline$>25$ & 79 & 29.3 \\
\hline \multicolumn{3}{|l|}{ Graduation institution } \\
\hline Private & 101 & 37.4 \\
\hline Public & 169 & 62.6 \\
\hline \multicolumn{3}{|l|}{ Specialist } \\
\hline No & 52 & 19.3 \\
\hline Yes & 218 & 80.7 \\
\hline \multicolumn{3}{|l|}{ Frequency of surgery } \\
\hline Never & 78 & 28.9 \\
\hline Rarely & 57 & 21.1 \\
\hline Sometimes & 54 & 20.0 \\
\hline Often & 54 & 20.0 \\
\hline Always & 27 & 10.0 \\
\hline \multicolumn{3}{|l|}{ Frequency of treating athletes } \\
\hline Never & 42 & 15.6 \\
\hline Rarely & 138 & 51.1 \\
\hline Sometimes & 74 & 27.4 \\
\hline Often & 12 & 4.4 \\
\hline Always & 4 & 1.5 \\
\hline
\end{tabular}

presented good discriminating properties, with a significant difference in scores between the groups of dentists who perform surgeries less or more frequently. The scientific literature evaluating the domain of pharmacology and prescriptions among the different areas of dentistry is sparse. However, these data may indicate that, as dentists who perform surgeries more frequently also prescribe drugs more frequently (due to the procedures), these professionals may have greater knowledge of the mechanisms of action of these substances and, consequently, on their potential capacity to increase the performance of athletes, which characterises sports doping.

\section{Main study}

In general, the demographic characteristics of this study were compatible with the national panorama of Brazilian dentists. The highest percentage of professionals in the main study practiced in the south and southeast regions, which is compatible with the proportion of dentists working in these regions (68.5\%) according to the Federal Council of Dentistry of Brazil (FCD), ${ }^{10}$ showing that this study provides a national panorama of knowledge about sports doping by dentists in the country. Although we can consider that the numerical representativeness of the sample in relation to the distribution by regions is according to the panorama of the country, the final sample is not homogeneous enough, since it is predominantly female. However, though the FCD does not make available on its website the general percentage of dentists according to sex, among experts, the entity states that, as in our study, most are female. ${ }^{12}$ In addition, another point to be discussed is that Brazil is a continental country, with a disproportion between counties inland and capitals, which may explain the predominance of dentists working inland than in the capitals, as identified in the study by Martin et al. ${ }^{13}$

Table 4. Coefficients of the simple and multiple linear regression models for predicting knowledge about sports doping in dentists.

\begin{tabular}{lcc}
\hline Independent variable & \multicolumn{2}{c}{ B-KSSDD score } \\
\cline { 2 - 3 } Age (years) & $\beta_{\text {crude }}(P$-value $)$ & $* \beta_{\text {adiusted }}(P$-value $)$ \\
Frequency of surgery (ordinal) & $-0.032(0.034)$ & $-0.032(0.034)$ \\
Frequency of treating athletes (ordinal) & $0.400(0.005)$ & $0.298(0.036)$ \\
\hline
\end{tabular}

${ }^{*}$ p-value model $<0.001 ;$ R2 $=0.08$. 
The average score obtained by dentists on the B-KSSDD in the main study shows that, in general, these professionals have insufficient knowledge about sports doping, increasing the risk that their athlete patients are inadvertently exposed to drugs that contain substances prohibited by the WADA. Although our sample contains a small number of specialists in Sports Dentistry, we observed that the average score of these professionals was approximately two times higher than that found in the total sample, suggesting that they are better able to provide dental care to athletes without placing them at risk if they are subjected to doping control. However, until March 2021, the FCD indicated that there were only 29 professional specialists in Sports Dentistry in the entire country, representing $0.02 \%$ of Brazilian dentists who have a specialisation course. Thus, the percentage of specialists in Sports Dentistry collected by our study is compatible with the small number of professionals in this field in the country. ${ }^{12}$

The simple and multiple linear regression models for predicting knowledge about sports doping among dentists showed that age has a negative association with knowledge about sports doping, which may be related to the fact that the establishment of Sports Dentistry and the increase in training programmes in this area are recent. ${ }^{14}$ In contrast, the frequencies of treating athletes or performing surgeries showed positive associations with knowledge about doping in the preliminary study. In this sense, it is highly recommended that, when seeking dental treatment, athletes and clubs hire dentists with experience in serving athletes in order to reduce the risk of punishments applied when sports doping is identified.

On the care of athletes, $5.9 \%$ of the participants said that they attend to athletes frequently (always or often). We believe that the low percentage can be justified by the fact that dentists can consider only elite athletes as "athletes". However, the role of sportsrelated dentistry is also intended to benefit the health of amateurs and recreational sports practitioners, who may also eventually be subjected to doping control. ${ }^{15}$ In addition, international literature shows that, even among elite athletes, oral health is poor, suggesting that these professionals access dental care services infrequently. ${ }^{16,17,18}$ In Brazil, for example, where soccer is the main national sport, although the Brazilian Football Confederation requires that, to be considered a training club, an entity must guarantee constant dental care at a preventive or therapeutic level to athletes in training, whether through their own services, contracted or outsourced..$^{19}$ However, Rosa et al. ${ }^{20}$ and Souza et al. ${ }^{21}$ showed that young soccer players included in their samples had poor oral health, confirming our hypothesis that this population's access to dental services is naturally low.

\section{B-KSSDD applications}

This study demonstrates that the B-KSSDD is a good instrument to use in different groups of dentists, respecting cross-cultural adaptations, to assess their knowledge on substances that, when prescribed to athletes, may result in sports doping. In the face of financial and sporting punishments applied to the world sports community when doping tests return positive results, applying the B-KSSDD may help the worldwide research community and international entities identify deficiencies in dentists' knowledge about prescribed drugs that can be characterised as sports doping, preventing these professionals from contributing to this important problem that can generate severe punishments and losses for athletes. The results found using the B-KSSDD show that the participants' knowledge about substances prohibited by the WADA is insufficient, making athletes treated by these professionals vulnerable to the punishments indicated in the Code. Together with the results found by Mottram et al., ${ }^{22}$ who applied a questionnaire on doping that included 507 athletes, of whom only 35.1\% correctly identified items on the prohibited list, the results of the present study are an alert to competent sports entities to create and/or reinforce policies to expand knowledge about sports doping among athletes, so that they can also act as disseminators of this information to health professionals who provide care to them, including dentists.

The results obtained using the B-KSSDD are also compatible with a review with a systematic search strategy, that found six articles involving health professionals (only doctors and pharmacists were found) and knowledge about doping, indicating that these professionals have limited knowledge about 
sports doping and the substances that characterise it. ${ }^{23}$ Moreover, Woods and Moynihan, ${ }^{24}$ showed only $9 \%$ of general practitioners in medicine said they felt prepared to act to prevent doping. This suggests that, at least among the classes evaluated by the scientific community, knowledge about sports doping is a challenge for the entire health spectrum of professionals. For that reason, prevention programmes and information on sports doping should be developed and offered to athletes, doctors, coaches and family members. ${ }^{25}$ Thus, the results obtained using the B-KSSDD can also promote the development of awareness and continuing education programmes on sports doping for dentists, decreasing the risk that athletes commit accidental sports doping as a result of dental care.

\section{Study limitation}

This study had limitations common in works involving questionnaires, which include the veracity of the information provided by the respondents and their commitment when answering the survey, which are also related to the comprehensibility and fluidity of the instrument. However, these limitations were reduced by the rigorous validation processes adopted during the development of B-KSSDD, described in this article. In addition, given that the scale was developed and validated in Brazilian Portuguese, this could be considered a limitation for its application in other countries, which in turn could be made possible through the cross-cultural adaptation and validation of the version suggested for the B-KSSDD in British English, available in Table 5.

Table 5. English version (not validated) suggested for the Brazilian Knowledge Scale about Sports Doping in Dentistry (B-KSSDD) and scores added to the total score according to the participants' responses.

\begin{tabular}{|c|c|c|c|}
\hline $\begin{array}{l}\text { Read the following sentences and inform your agreement, disagreement or lack of } \\
\text { knowledge about the statement presented: }\end{array}$ & Agree & Disagree & Don't know \\
\hline $\begin{array}{l}\text { 1. The use of oral nimesulide (for example, Nisulid }(\text {, Arflex } ® \text { ), prescribed by a dental } \\
\text { surgeon to an athlete who is in competition, characterises sports doping. }\end{array}$ & 0 & 1 & 0 \\
\hline $\begin{array}{l}\text { 2. The use of oral dexamethasone (for example, Decadron), prescribed by a dental } \\
\text { surgeon to an athlete who is in competition, characterises sports doping. }\end{array}$ & 1 & 0 & 0 \\
\hline $\begin{array}{l}\text { 3. The use of oral dipyrone (for example, Novalgina }{ }^{\circledR}, \text { Dorflex } \AA, \text { Magnopirol }(\text { ), } \\
\text { prescribed by a dental surgeon to an athlete who is in competition, characterises } \\
\text { sports doping. }\end{array}$ & 0 & 1 & 0 \\
\hline $\begin{array}{l}\text { 4. The use of topical triamcinolone (for example, Omcilon } ® \text { ), prescribed by a dental } \\
\text { surgeon to an athlete who is in competition, characterises sports doping. }\end{array}$ & 0 & 1 & 0 \\
\hline $\begin{array}{l}\text { 5. The use of a local anesthetic with adrenaline or epinephrine (for example, } \\
\text { Aplhacaine) administered by a dental surgeon in an athlete who is in a competition } \\
\text { period characterises sports doping. }\end{array}$ & 0 & 1 & 0 \\
\hline $\begin{array}{l}\text { 6. The use of a combination of dipyrone with oral isometheptene (for example, in } \\
\left.\text { Neosaldina }{ }^{\circledR}\right) \text {, prescribed by a dental surgeon to an athlete who is in competition, } \\
\text { characterises sports doping. }\end{array}$ & 1 & 0 & 0 \\
\hline $\begin{array}{l}\text { 7. The use of oral prednisolone (for example, Predsim } \AA \text { ), prescribed by a dental } \\
\text { surgeon to an athlete who is in competition, characterises sports doping. }\end{array}$ & 1 & 0 & 0 \\
\hline $\begin{array}{l}\text { 8. The use of oral amoxicillin (for example, in Amoxil }(\text { ), prescribed by a dental } \\
\text { surgeon to an athlete who is in competition, characterises sports doping. }\end{array}$ & 0 & 1 & 0 \\
\hline $\begin{array}{l}\text { 9. The use of oral acetaminophen (for example, Tylenol } \circledast \text { ), prescribed by a dental } \\
\text { surgeon to an athlete who is in competition, characterises sports doping. }\end{array}$ & 0 & 1 & 0 \\
\hline $\begin{array}{l}\text { 10. The use of an oral combination of codeine with acetaminophen (for example, } \\
\text { Tylex }(\text { ), prescribed by a dental surgeon to an athlete who is in competition, } \\
\text { characterises sports doping. }\end{array}$ & 0 & 1 & 0 \\
\hline $\begin{array}{l}\text { 11. The use of oral ibuprofen (for example, Alivium }{ }^{\circledR} \text { ), prescribed by a dentist to an } \\
\text { athlete who is in competition, characterises sports doping. }\end{array}$ & 0 & 1 & 0 \\
\hline $\begin{array}{l}\text { 12. The use of oral betamethasone (for example, Celestone }{ }^{\circledR} \text { ), prescribed by a dental } \\
\text { surgeon to an athlete who is in competition, characterises sports doping. }\end{array}$ & 1 & 0 & 0 \\
\hline Total score & & $0-12$ points & \\
\hline
\end{tabular}

Correct answers are represented by 1 and incorrect or "I don't know" are represented by 0 points in the final B-KSSDD score. 


\section{Conclusions}

The instrument proved to be valid and reliable in assessing dentists' knowledge about sports doping. Dentists had insufficient knowledge about sports doping, obtaining an average score of 4.19 out of 12 points on the B-KSSDD. Lower age of the professional and higher frequencies of performing surgery and treating athletes were associated with greater knowledge about sports doping. The development of professional updating policies on sports doping for dentists is important to prevent the intentional practice of doping by athletes after dental care.

\section{Acknowledgements}

We acknowledge the professionals who worked during the initial evaluation of B-KSSDD questions. No sources of funding were used to assist in the preparation of this article. Lucas Alves Jural is supported by a research Grant (147858/2020-8) from the Institutional Program for Scientific Initiation Scholarships (PIBIC) of the Conselho Nacional de Desenvolvimento Científico e Tecnológico (CNPq). Thais Rodrigues Campos Soares is supported by a research Grant (159961/2018-1) from the CNPq. Matheus Melo Pithon is supported by a research Grant (309800/2019-6) from the CNPq. Lucianne Cople Maia is supported by a research Grant from the Fundação de Amparo à Pesquisa do Estado do Rio de Janeiro (E-26/210.208/2018) and from CNPq (310225/2020-5).

\section{References}

1. Goldman B, Klatz R. Death in the locker room: drugs and sports paperback. Dacula: Elite Sports Medicine; 1992.

2. Voy RO, Deeter KD. Drugs, sport, and politics. Champaign: Leisure; 1991.

3. The International Federation of Sports Medicine. FIMS position statement: statement on doping in sport. Lausanne: The International Federation of Sports Medicine; [cited 2020 Jun 16]. Available from: https://www.fims.org/files/4414/2056/2561/PS13-Statement-onDoping-in-Sport.pdf

4. World Anti-doping Agency. World anti-doping code; 2012 with 2019 amendments. 2 ed. Montreal: World Anti-doping Agency; 2019 [cited 2020 Jun 26]. Available from: https://www.wada-ama.org/sites/default/files/resources/files/wada_anti-doping_code_2019_ english_final_revised_vl_linked.pdf

5. World Anti-doping Agency. The World Anti-Doping Code: international standard: phohibited list; january 2020. Montreal: World Anti-doping Agency; 2020. Available from: https://www.wada-ama.org/sites/default/files/wada_2020_english_prohibited_list_0.pdf

6. Moore PA, Nahouraii HS, Zovko JG, Wisniewski SR. Dental therapeutic practice patterns in the U.S. II. Analgesics, corticosteroids, and antibiotics. Gen Dent. 2006;54(3):201-7; quiz 08, 21-2.

7. Pluim B. A doping sinner is not always a cheat. Br J Sports Med 2008;42(7):549-50.8.

8. Terwee CB, Bot SD, Boer MR, Windt DA, Knol DL, Dekker J, et al. Quality criteria were proposed for measurement properties of health status questionnaires. J Clin Epidemiol. 2007 Jan;60(1):34-42. https://doi.org/10.1016/i.jclinepi.2006.03.012

9. Hulley SB, Cummings SR, Browner WS, Grady D, Hearst N, Newman TB. Delineando a pesquisa clínica: uma abordagem epidemiológica. 2th ed. Porto Alegre: Artmed; 2003.

10. Conselho Federal de Odontologia. Dados estatísticos de profissionais e entidades ativas por localidade. Brasília, DF: Conselho Federal de Odontologia; 2020 [cited 2020 Jun 15]. Available from: https://www.website.cfo.org.br/dados-estatisticos-de-profissionais-eentidades-ativas-por-localidade/

11. Elbe AM, Jensen SN, Elsborg P, Wetzke M, Woldemariam GA, Huppertz B, et al. The urine marker test: an alternative approach to supervised urine collection for doping control. Sports Med. 2016 Jan;46(1):15-22. https://doi.org/10.1007/s40279-015-0388-6

12. Conselho Federal de Odontologia. Quantidade geral de cirurgiões-dentistas especialistas. Brasília, DF: Conselho Federal de Odontologia; 2021 [cited 2021 Mar 8]. Available from: https://website.cfo.org.br/estatisticas/quantidade-geral-de-cirurgioesdentistas-especialistas/

13. Martin ASS, Chisini LA, Martelli S, Sartori LRM, Ramos EC, Demarco FF. Distribution of dental schools and dentists in Brazil: an overview in relation to labor market. Rev Abeno. 2018 Mar.18(1):63-73. https://doi.org/10.30979/rev.abeno.v18i1.399

14. Saini R. Sports dentistry. Natl J Maxillofac Surg. 2011 Jul;2(2):129-31. https://doi.org/10.4103/0975-5950.94465

15. Stamos A, Mills S, Malliaropoulos N, Cantamessa S, Dartevelle JL, Gündüz E, et al. The European Association for Sports Dentistry, Academy for Sports Dentistry, European College of Sports and Exercise Physicians consensus statement on sports dentistry integration in sports medicine. Dent Traumatol. 2020 Dec;36(6):680-4. https://doi.org/10.1111/edt.12593 
16. Gallagher J, Ashley P, Petrie A, Needleman I. Oral health and performance impacts in elite and professional athletes. Community Dent Oral Epidemiol. 2018 Dec;46(6):563-8. https://doi.org/10.1111/cdoe.12392

17. Needleman I, Ashley P, Petrie A, Fortune F, Turner W, Jones J, et al. Oral health and impact on performance of athletes participating in the London 2012 Olympic Games: a cross-sectional study. Br J Sports Med. 2013 Nov;47(16):1054-8. https://doi.org/10.1136/bjsports-2013-092891

18. Kragt L, Moen MH, Van Den Hoogenband CR, Wolvius EB. Oral health among Dutch elite athletes prior to Rio 2016. Phys Sportsmed. 2019 May;47(2):182-8. https://doi.org/10.1080/00913847.2018.1546105

19. Confederação Brasileira de Futebol. Resolução da Presidência nº 01/2029: Modifica e substitui as RDPs n 01/2012 e 04/2015, que estabelecem normas para a emissão de Certificado de Clube Formador (CCF). [cited 2021 Mar 8]. Available from: https://conteudo.cbf. com.br/cdn/202009/20200918145239_131.pdf

20. Rosa AF, Costa SB, Silva PR, Roxo CD, Machado GS, Teixeira AA, et al. [Descriptive study of odontological alterations verified in four hundred soccer players]. Rev Bras Med Esporte. 1999 Apr;5(2):55-8. Portuguese. https://doi.org/10.1590/S1517-86921999000200004

21. Souza LA, Elmadjian TR, Dias RB, Coto NP. Prevalence of malocclusions in the 13-20-year-old categories of football athletes. Braz Oral Res. 2011 Jan-Feb;25(1):19-22. https://doi.org/10.1590/S1806-83242011000100004

22. Mottram D, Chester N, Atkinson G, Goode D. Athletes' knowledge and views on OTC medication. Int J Sports Med. 2008 Oct;29(10):851-5. https://doi.org/10.1055/s-2008-1038403

23. Backhouse SH, McKenna J. Doping in sport: a review of medical practitioners' knowledge, attitudes and beliefs. Int J Drug Policy. 2011 May;22(3):198-202. https://doi.org/10.1016/i.drugpo.2011.03.002

24. Woods CB, Moynihan A. General practitioners knowledge, practice and training requirements in relation to doping in sport. Ir Med J. 2009 Jan; 102(1):8-10.

25. Morente-Sánchez J, Zabala M. Doping in sport: a review of elite athletes' attitudes, beliefs, and knowledge. Sports Med. 2013 Jun;43(6):395-411. https://doi.org/10.1007/s40279-013-0037-x 